\title{
4 \\ Global production sharing and US-China trade relations
}

\section{Prema-chandra Athukorala and Nobuaki Yamashita}

In the past decade, the widening bilateral trade deficit has been the focal point of US-China economic relations. This is often portrayed as a cause of the overall US current account imbalance. Real public concerns in the United States surrounding the debate about the 'China deficit' are, however, rooted in the perceived economic threat of import competition. In the late 1990s, when imports from China were dominated by traditional labour-intensive manufactures such as clothing and footwear, unskilled workers' employment losses and wage suppression were the prime focus of the debate. More recently, the apparent rising sophistication of imports from China-in particular, the sharp rise in imports of computers and electronic products-has fuelled concerns that the rise of China poses a direct threat to the United States' position as a technology superpower, a concern reminiscent of the economic fears about Japan that pervaded the US policy scene in the 1970s and 1980s.

'Unfair' Chinese import competition is perceived to take a number of forms, including illegal export subsidies, lax enforcement of intellectual property rights, restrictions on imports to and foreign investment in China, and the national currency being kept undervalued through massive intervention in the foreign exchange market (Hufbauer et al. 2006; Mankiw and Swagel 2005; Weisman 2007). These concerns have fuelled calls for new legislation to prevent unfair practices. In February 2005, the US Senate passed the Byrd Amendment, a provision that encouraged American companies to file anti-dumping lawsuits 
by awarding revenue collected from the resultant tariffs to litigating companies. Other China-specific legislation has been proposed in the past two years, including a bill that stipulates declaring exchange rate protection as a form of illegal subsidisation for which US firms can seek compensation. The economic Sinophobia has also begun to spill over to other arenas of US-China relations, including international food-safety standards and US policy postures relating to the entry of Chinese firms in the corporate arena (Shirk 2007:267). The China threat-in particular, the loss of American jobs to China-was a hot issue in the 2000 and 2004 presidential elections, and indications are that it is likely to figure even more prominently in the upcoming (2008) presidential campaign (Easton 2008; Steinbock 2008).

The policy debate about US-China trade relations has so far been based on the conventional notion of horizontal specialisation, in which trade takes place in the form of final goods (goods that are produced from start to finish in a given country). It has largely ignored the continuing process of global production sharing - the break-up of the production process into geographically separated stages ${ }^{1}$-and the resulting trade complementarities between the two countries as dominant players of this new form of international exchange. Global production sharing opens up opportunities for countries to specialise in different slices (different tasks) of the production process depending on their relative cost advantage and other relevant economic fundamentals. Consequently, parts and components are now exchanged across borders at a faster rate than final goods. In this context, decisions about how much to produce and for which market have to be combined with decisions about whether to produce and with what degree of intra-product specialisation. The upshot is that trade-flow analysis based on data coming from a reporting system designed at a time when countries were trading only in final goods naturally distorts values of exports and imports, leading to a falsification of the current account imbalances. The degree of falsification is likely to increase over time as more complex production networks are created with an ever-increasing number of interacting countries (Jones and Kierzkowski 2001a, 2001b). The spread of international production sharing can also diminish the efficacy of exchange rate and tariff policies in influencing trade flows by opening up opportunities for firms to acquire inputs from, and relocate final assembly to, different countries within global production networks, with a view to cushioning their profit margins in the face of such policy changes (Ghosh and Rajan 2007).

Given the current state of data, it is not possible to quantify the effect of international production sharing on bilateral trade imbalances: this would require a major overhaul of the international system of collecting trade data 
to record domestic value-added content at different stages of production. The COMTRADE database of the United Nations (UN various years) does, however, now provide disaggregated data that permit the separation of parts and components from final goods with a satisfactory coverage of trade in machinery and transport equipment, a commodity class in which most of the global production sharing is concentrated. Data extracted from this source, when combined with the available case study-based evidence of global operations of multinational enterprises, permit us to paint a broad-bush picture of the nature of the continuing process of global production sharing and its implications for US-China trade relations in order to better inform the current policy debate. That is what we aim to do in this chapter. A number of recent studies have alluded to the importance of paying attention to global production sharing in analysing the drivers of the US-China trade deficit (Bergsten et al. 2006; Lardy 2005; Fung et al. 2006; Krugman 2008). To our knowledge, however, this is the first attempt to examine this issue systematically to the extent permitted by the available data.

The remainder of this chapter is presented in four parts. The next section offers an overview of trends and patterns of Chinese trade in order to set the stage for the ensuing analysis. The third section surveys US-China trade patterns with emphasis on emerging patterns in the two countries' involvement in global production networks and their implications for the bilateral trade flows using some fresh datum tabulations separating trade in parts and components and final goods in machinery trade. This is followed by an econometric analysis of the determinants of trade flows. The final section presents concluding remarks.

\section{China's trade performance: an overview}

The rise of China as a major trading nation was one of the most momentous developments of the post-World War II era, surpassing even the stunning rise of Germany and Japan. Total merchandise exports from China increased from US $\$ 8$ billion (about 1 per cent of global exports) in 1978-79, when the process of liberalisation reforms started, to US $\$ 1,442$ billion (13.4 per cent) in 2005-06. ${ }^{2}$ In 2006, China was the second largest exporting nation in the world after Germany and, assuming the current growth rates continue, it will become the largest in about 10 years. During the reform era, until about the mid 1980s, imports followed exports closely with periodic minor trade surpluses or deficits. From then on, exports have persistently outpaced imports, yielding a mild annual surplus averaging about 2 per cent of gross domestic product (GDP), and exceeding 3 per cent only briefly, in 1997-98. 
China's phenomenal export expansion has been underpinned by a shift in the commodity composition of exports away from primary products and towards manufacturing (Table 4.1). The share of manufactures in China's total merchandise exports increased from less than 40 per cent in the late 1970s to nearly 80 per cent in the early 1990s, and to 92 per cent in 2005-06. Until about the late 1990s, traditional labour-intensive manufactures-in particular, apparel, footwear, toys and sporting goods-were the prime movers of export expansion. Since then, there has been a notable shift in the export composition away from conventional labour-intensive product lines and towards more sophisticated product lines-in particular, those within the broader Standard International Trade Classification (SITC) category of machinery and transport equipment (SITC 7; henceforth referred to as 'machinery'). Between 1992-93 and 2005-06, the share of miscellaneous manufactures (SITC 8)-a catchall commodity group encompassing most of the traditional labour-intensive products-declined from 49 per cent to 31 per cent and the share of machinery increased from 17 per cent to 44 per cent.

The expansion of machinery exports has been brought about by China's highly publicised export success in a wide range of 'information and communication technology' (ICT) products (which fall under SITC categories 75,76 and 77). China's world market share of ICT products recorded a fivefold increase from 5 per cent in 1992-93 to 24.1 per cent in 2005-06. Among them, the share of office machines increased from less than 2 per cent in 1992-93 to more than 28 per cent in 2005-06. Today, China is the world's largest global producer as well as the single largest exporter of personal computers falling in this commodity group. China's world market share of telecommunications and sound-recording equipment (dominated by mobile phones, DVD players and CD players) was 26.2 per cent in 2005-06-up from 7.9 per cent in 1992-93.

Trade data showing this phenomenal structural shift have been used widely - not only in the popular press and policy reports of agencies involved in promoting research and development activities, but in some scholarly writing - to argue that China is rapidly becoming an advanced-technology superpower and the sophistication of its export basket is rapidly approaching the levels of those of most advanced industrial nations (for example, Rodrik 2006; Yusuf et al. 2007). A closer examination of the data, however, suggests that such an inference is fundamentally flawed. In reality, what we observe is the rapid consolidation in China of the final-assembly stages of East Asiancentred global production networks for these products. Ample supplies of relatively cheap and trainable labour and the scales of economy arising from China's vast domestic market (which enables firms to achieve low unit costs) 


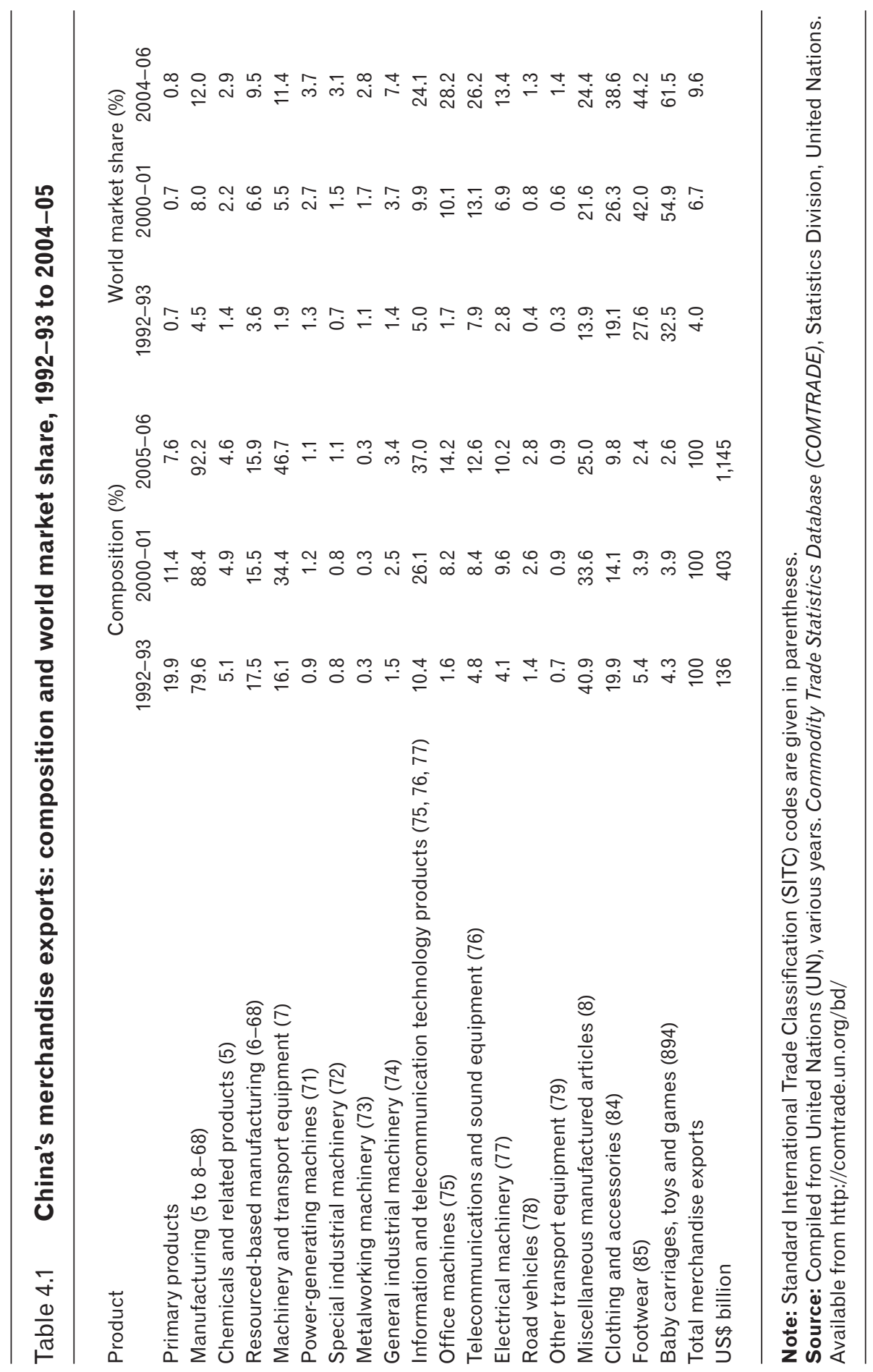


are contributing factors to China's attractiveness as a global assembly centre. As already noted, China's so-called 'high-tech' exports are concentrated heavily in a single product category: ICT products. The bulk of these products (such as notebook computers, display units, mobile phones and DVD and CD players) are simply 'mass-market commodities' produced in huge quantities and at relatively low unit costs using imported high-tech parts and components; they are not leading-edge technology products.

The share of components in total machinery imports to China increased from 32.5 per cent in 1992-93 to 63.4 per cent in 2004-05, with the import shares of the three ICT products (SITC 75, 76 and 77) recording much faster growth (Table 4.2). In contrast, final goods (total exports minus components) have continued to dominate the export composition. In the past decade, the share of final goods in total machinery exports has remained about 75 per cent, with only minor year-to-year changes. Given the fact that the production of parts and components is generally more capital and technology intensive than final assembly, these figures clearly suggest that China's export success has so far been underpinned largely by its comparative advantage in international production arising from its labour abundance. When components are netted out, more than 80 per cent of total Chinese manufacturing exports can still be treated as labour-intensive products.

The bulk of assembly activities in China are carried out by affiliates of multinational enterprises ('foreign-invested enterprises', FIEs) from imported components within their global production networks (Dean and Tam 2005; Naughton 2007; Sung 2007). The share of FIEs in total exports from China

\section{Table 4.2 Share of parts and components in China's manufacturing trade, 1992-93, 2000-01 and 2005-06}

\begin{tabular}{lrccccc} 
Product & \multicolumn{3}{c}{ Exports } & \multicolumn{3}{c}{ Imports } \\
& $1992-93$ & $2000-01$ & $2005-06$ & $1992-93$ & $2000-01$ & $2005-06$ \\
Total manufacturing & 17.93 & 32.56 & 40.77 & 6.86 & 14.98 & 18.39 \\
Machinery and transport & 36.51 & 58.98 & 67.65 & 33.95 & 38.50 & 36.32 \\
$\quad$ equipment (7) & & & & & & \\
ICT products (75, 76, 77) & 59.90 & 72.70 & 79.20 & 32.53 & 37.91 & 34.83 \\
Miscellaneous manufacturing (8) & 20.66 & 15.49 & 10.89 & 1.47 & 1.69 & 2.35
\end{tabular}

Note: Standard International Trade Classification (SITC) codes are given in parentheses. Source: Compiled from United Nations (UN), various years. Commodity Trade Statistics Database (COMTRADE), Statistics Division, United Nations, New York. Available from http:// comtrade.un.org/bd. 
increased from less than 2 per cent in 1980 to more than 58 per cent by 2005 . They accounted for 88 per cent of total information-technology products exported from China in 2005. The FIEs are mostly wholly foreign owned, and their activities in China are concentrated overwhelmingly in the final-assembly stage of production, which is the most labour-intensive layer of a production process spread across many countries. Basic research and product design and capital and human capital-intensive stages of the production process are carried out in the home countries of the multinational enterprises or in other Asian countries that are in a more advanced stage of industrial development than China. Affiliates of US multinationals account directly for only a small share of total exports by FIEs (about 10 per cent), ${ }^{4}$ with affiliated Taiwanese, Hong Kong and Korean firms accounting for the lion's share (of more than 80 per cent). US multinationals seem, however, to play a major role in parts and components supplies for all export-oriented assembly firms from their production bases in China and other countries-in particular, those located in Southeast Asia. ${ }^{5}$

\section{US-China trade patterns}

Bilateral trade between the United States and China has grown persistently since the early 1980s, with the rate of growth accelerating from about the mid 1990s and again after China's accession to the World Trade Organization (WTO) in 2001 (Figure 4.1). The value of US imports from China rose from US $\$ 16$ billion in 1990 to US $\$ 307$ billion in 2006. Since 2003, China has been the second largest source of US imports, after Canada but ahead of Mexico and Japan. US exports to China have also grown persistently during this period, but from a low base and at a slower rate. Total exports in 2006 amounted to a mere US $\$ 55$ billion, up from US $\$ 5$ billion in 1990. Bilateral economic ties between the two countries have therefore been characterised by a steadily growing trade imbalance: the trade deficit increased from US $\$ 11$ billion to US $\$ 205$ billion in 2006-the largest deficit the United States has ever had with any country. The bilateral trade deficit as a percentage of US GDP increased from 0.2 per cent in 1990 to 0.9 per cent in 2000, and then to 1.9 per cent in 2007. The deficit with China has been the United States' single largest bilateral trade deficit since 1999. As part of its WTO accession, China substantially reduced barriers to import trade, becoming the fastest growing market for US exports. China's WTO accession also gave foreign companies confidence to move their assembly plants within global production networks to China. As a result, China's exports kept growing.

Figure 4.2 illustrates the US-China trade deficit in the context of the United States' growing overall trade deficit. At the same time that the US deficit with 


\section{Figure 4.1 US-China trade, 1990-2006}

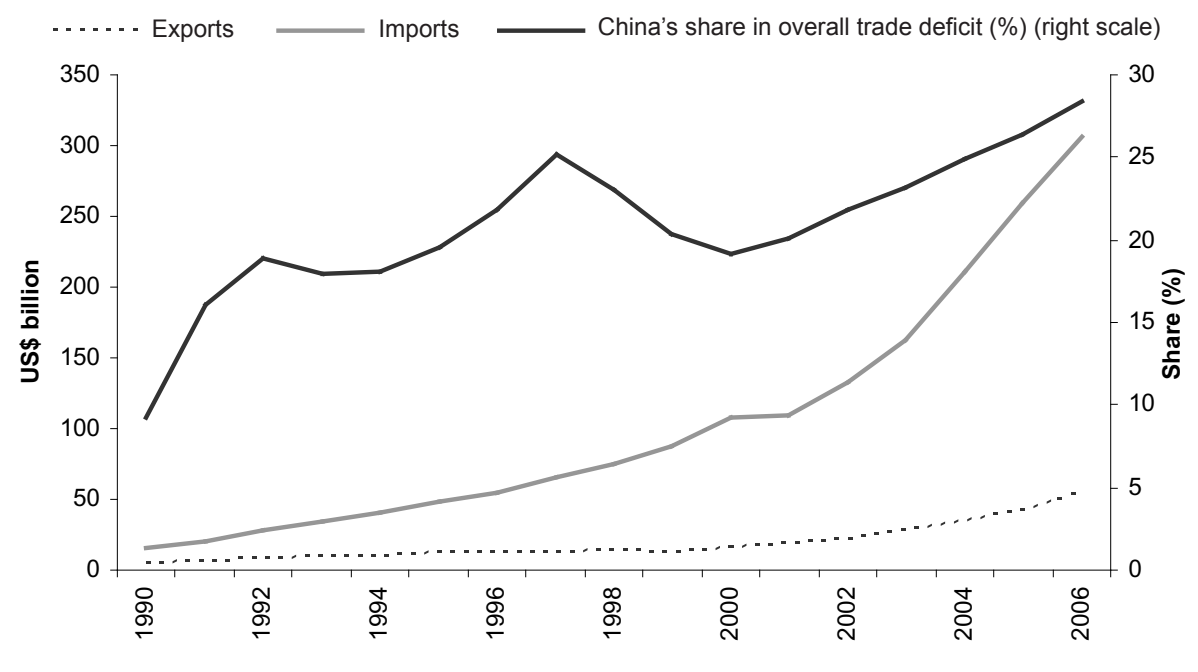

Figure 4.2 US trade deficit: China's share in comparative perspective, 1990-2006

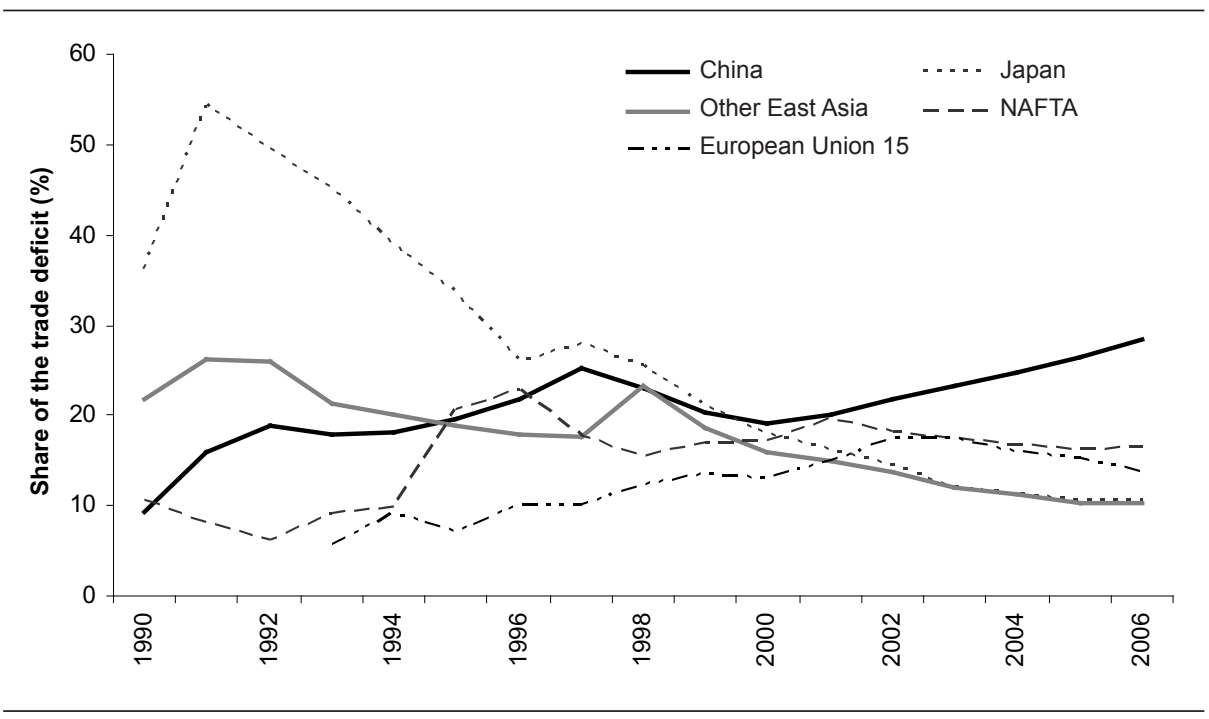

* the United States had a small trade surplus with the European Union during 1990-93 NAFTA $=$ North American Free Trade Agreement

Source: Based on data compiled from United Nations (UN), various years. Commodity Trade Statistics Database (COMTRADE), Statistics Division, United Nations, New York. Available from http://comtrade.un.org/bd. 
China increased, the overall US deficit with all other countries has expanded. In 2006, the US-China bilateral deficit amounted to 28 per cent of the total US trade deficit-in other words, almost three-quarters of the total US trade deficit with the rest of the world. This comparison suggests that current US policy concerns about Chinese trade have been driven primarily by the perceived threat of import competition from China rather than by the broader economic issue of a widening overall trade imbalance.

Figure 4.2 also shows that, from about 1999, the widening US-China deficit has been significantly counterbalanced by a sharp decline in the relative importance of US bilateral trade deficits with Japan and other East Asian countries. Between 1999 and 2006, the increase in China's share in the total US trade deficit from 20.4 per cent to 28.4 per cent was accompanied by a decline in the respective figure for Japan-from 21.1 per cent to 10.5 per cent. The share of the other East Asian countries also declined -from 16 per cent to 10.3 per cent-between these two years. These contrasting patterns point to the fragility of any analysis of trade imbalances based only on 'reported' bilateral trade figures in an era of global production sharing — a point to be investigated using disaggregated trade data in the next section.

Figure 4.3 tells the Chinese side of the story. ${ }^{6}$ The widening China-US trade surplus in the past 10 years has been accompanied by widening bilateral deficits with Japan and the other East Asian countries. From 2004 to 2006, the combined deficit with Japan and the other East Asian countries amounted to 85 per cent of the China-US trade surplus. In fact, China has had an overall trade deficit with the world, excluding the United States, for several years now. There is evidence that China's widening trade deficits with its regional trading partners are closely associated with China's increasingly important role as the main centre of final assembly within regional production networks. At the beginning of the reform era, export-oriented firms in Hong Kong, Taiwan and Korea that were involved in the production of conventional labour-intensive products such as clothing, footwear, toys and travel goods relocated their production to China. This was followed, from about the early 1990s, by rapid relocation to China of the final-assembly stages of 'high-tech' industries-in particular, ICT industries from these countries and also from Japan, the United States and other industrial countries. During this period, the major member countries of the Association of Southeast Asian Nations (ASEAN; Singapore, Thailand, Malaysia and the Philippines) also began to participate in the production networks in a big way as suppliers of parts and components for final-assembly activities in China (Athukorala 2008). This massive restructuring of production processes within global production networks naturally set the stage for a shift 


\section{Figure 4.3 China's bilateral trade balance, 1992-2006 (US\$ billion)}

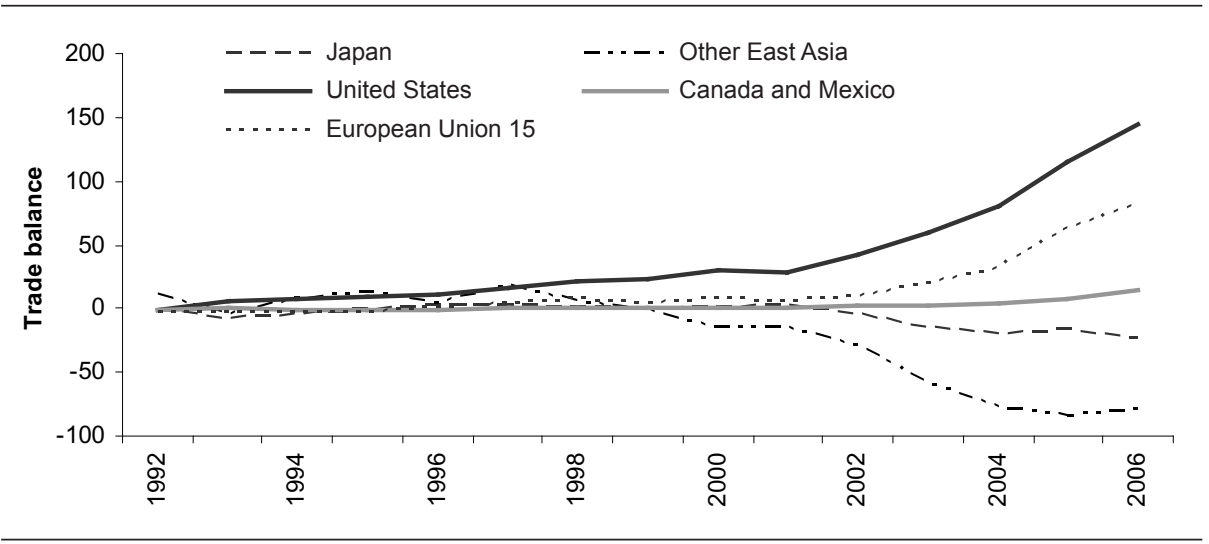

Source: Based on data compiled from United Nations (UN), various years. Commodity Trade Statistics Database (COMTRADE), Statistics Division, United Nations, New York. Available from http://comtrade.un.org/bd.

in China's growing bilateral trade surplus with the United States (and some other industrial countries), which provided markets for final (assembled) goods in its regional trading partners in the form of narrowing trade deficits and/or growing trade surpluses.

The discussion so far in this section suggests that the US-China trade imbalance could be largely a structural phenomenon, quite distinct from the overall trade imbalance of the United States, and related largely to the continuing process of global production sharing and the pivotal role played by China in this new form of international exchange. We now turn to disaggregated analysis of US-China trade flows in order to broaden our understanding of the phenomenon.

In the reform era, until about the early 1990s, traditional conventional labour-intensive manufactured goods (miscellaneous manufactures) dominated Chinese exports to the US, reflecting China's general pattern of export specialisation at the time. Since then there has been a palpable shift in the commodity composition of imports away from these products and towards machinery and transport equipment-in particular, ICT products. Between 1995-96 and 2005-06, the share of miscellaneous manufactures in total imports from China declined from 58.8 per cent to 38.5 per cent, accompanied by an increase in the share of machinery from 26.3 per cent to 44.1 per cent (Table 4.3). The share of ICT products increased from 22.4 per cent to 37.6 per cent, and this commodity group contributed to more than 40 per cent of the total 


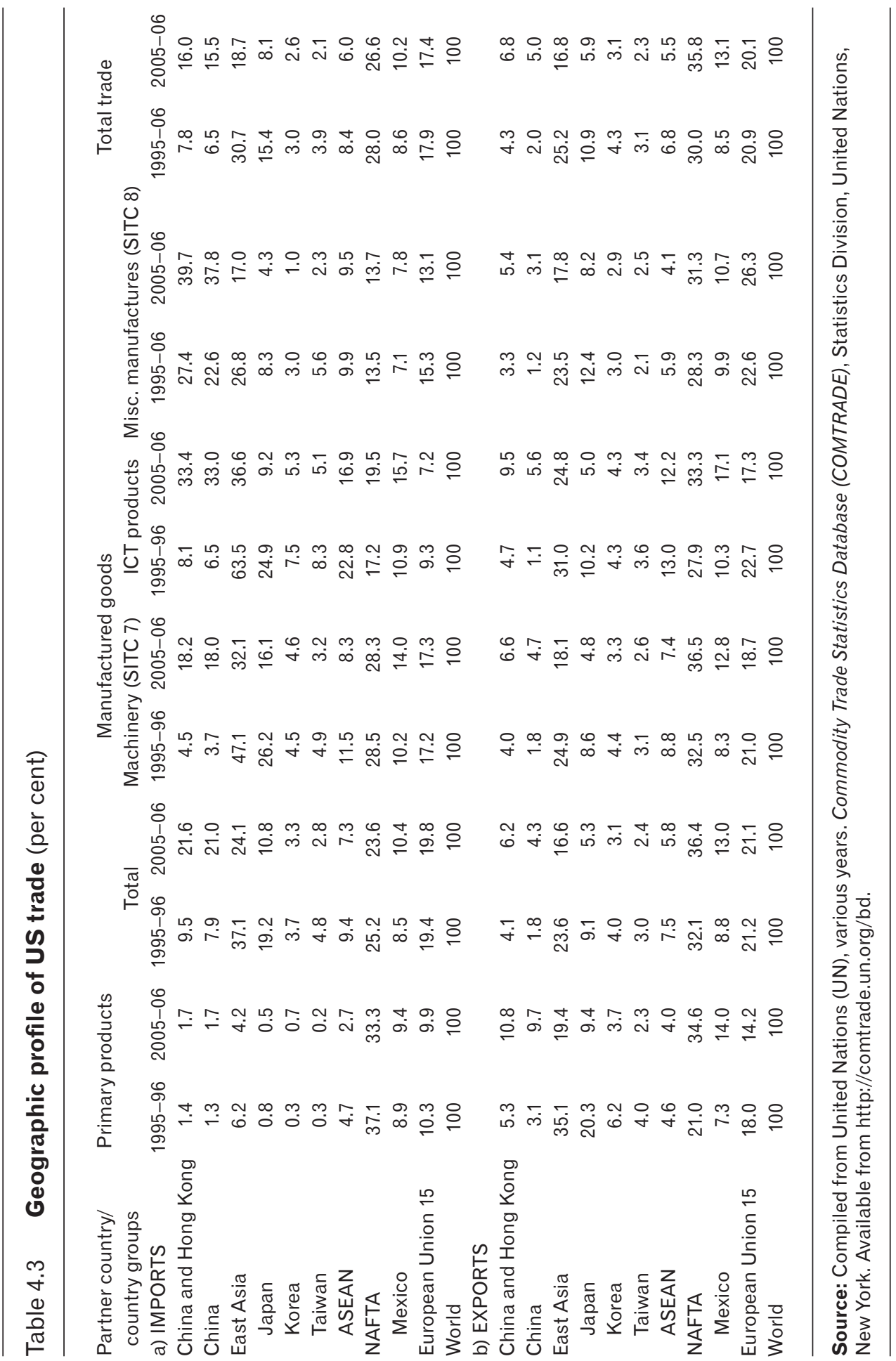




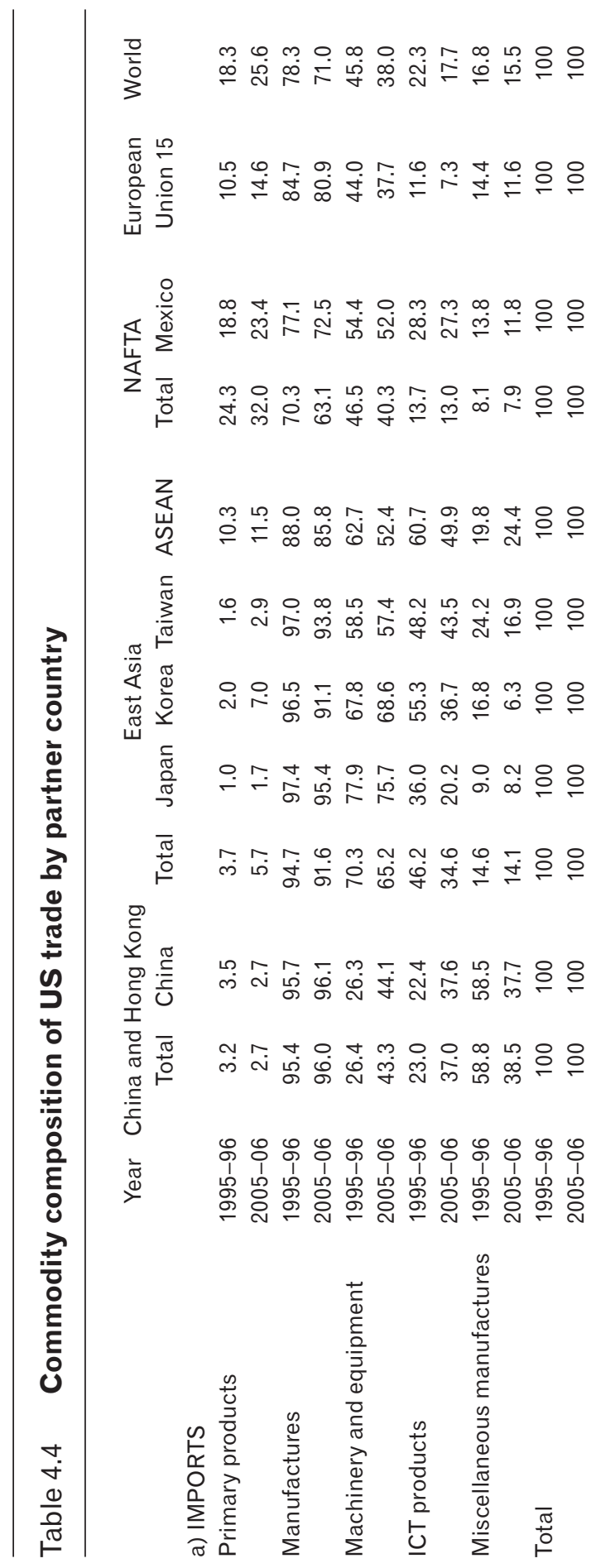




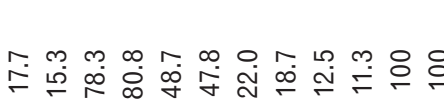

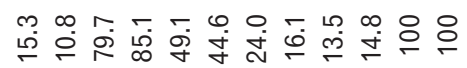

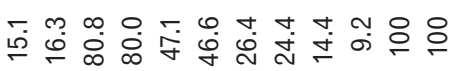

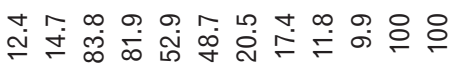

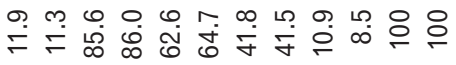

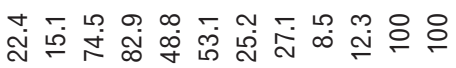

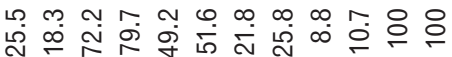

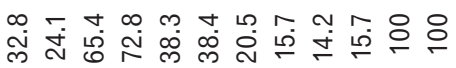

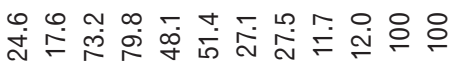

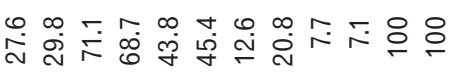

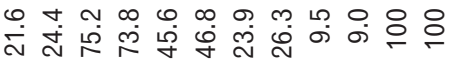

ㅇசㅇㅇㅇㅇ ச

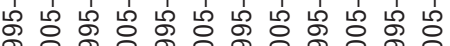

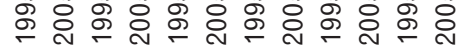

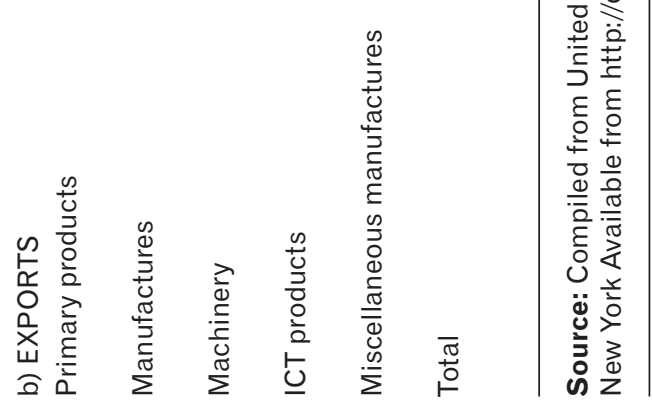


increment in imports from China between these two periods. China's share in total US ICT-product imports increased from 6.5 per cent in 1995-96 to 33 per cent in 2005-06 (Table 4.4). This was underpinned by a sharp decline in the combined share of the other East Asian countries-from 63.5 per cent to 36.6 per cent. China's share in US ICT imports in 2005-06 was almost two times that of Mexico (15.7 per cent).

To gain further insights into the growing importance of overseas assembly as a source of imports for the United States and the pivotal role played by China in this international division of labour, we disaggregated data for machinery trade into parts and components and final goods (reported trade: parts and components). The results of this exercise are presented in Figure 4.4 and Table 4.5. Table 4.5 gives data for the share of parts and components in total US imports and exports of machinery and the subcategory of ICT products therein. Data for ICT products disaggregated into final goods and parts and components are plotted in Figure 4.4.

The share of components in US machinery exports is generally much higher across all partner countries compared with that of imports (Table 4.5). Moreover, on the import side, the shares have recorded a notable decline across all importtrading partners. This decline is much sharper for the ICT products subcategory within the broader category of machinery and transport equipment. These patterns are generally consistent with the United States' comparative advantage in skill and capital-intensive activities in production processes within global production networks in vertically integrated industries. Within this broader context, one can observe two peculiarities relating to China's role in international production sharing in relation to its trade with the United States.

First, the share of parts and components in US exports to other East Asian countries (in particular, to the countries in ASEAN) is much higher compared with that of exports to China. This pattern is consistent with the case studybased findings that US firms located in East Asian countries undertake further processing/assembly of parts and components originally designed and/or produced in the United States as part of their engagement in China-centred regional production networks. United States-based multinational enterprises have a long history of engagement in parts and components assembly and testing in Southeast Asia, dating back to the setting up of processing plants by National Semiconductors and Hewlett Packard in Singapore in the early 1970s. Many more US firms entered this arena and their production locations expanded to Thailand, Malaysia and the Philippines in subsequent years and, more recently, to Vietnam. At the formative stage, the activities of US multinational enterprise affiliates involved assembly/testing of simple components and the re- 


\section{Figure 4.4 US trade in ICT goods disaggregated into parts and components and final goods, 1990-2006 (per cent)}
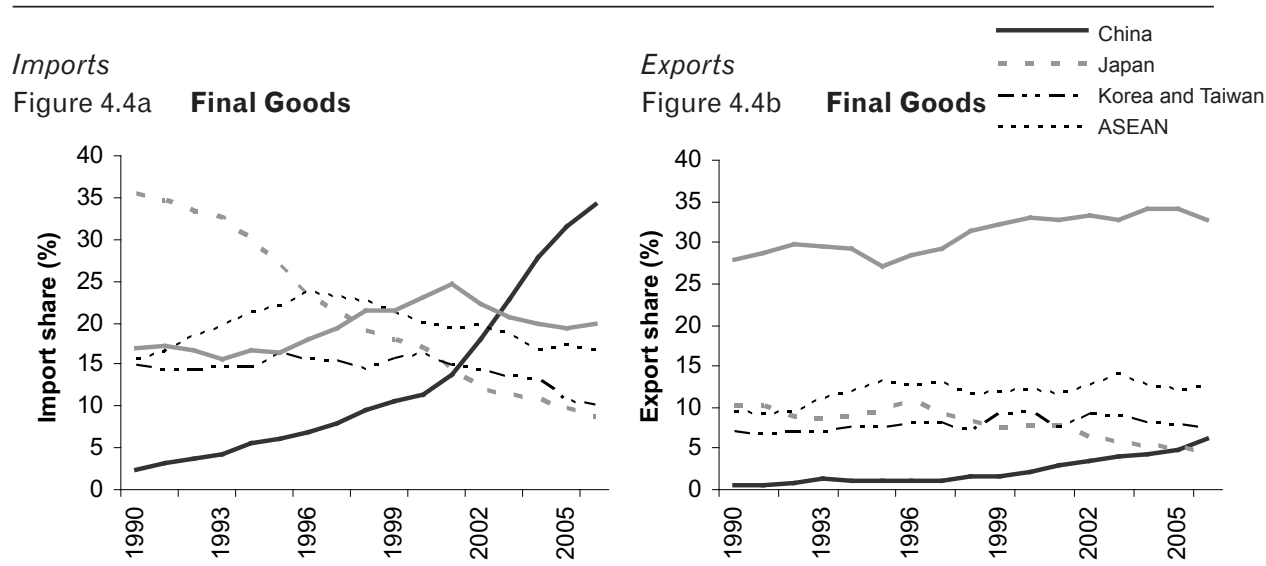

Figure 4.4c Parts and components
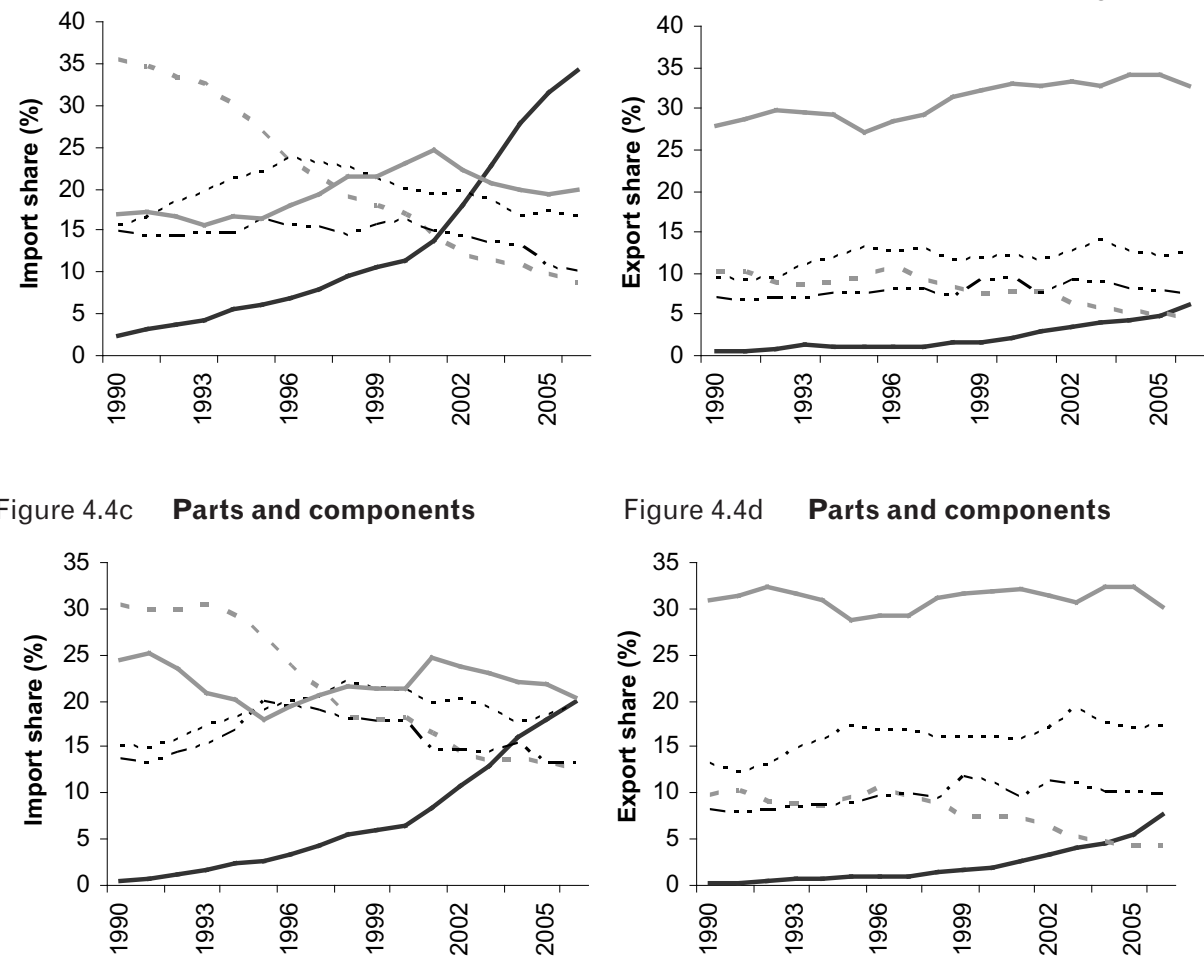

Figure 4.4d Parts and components

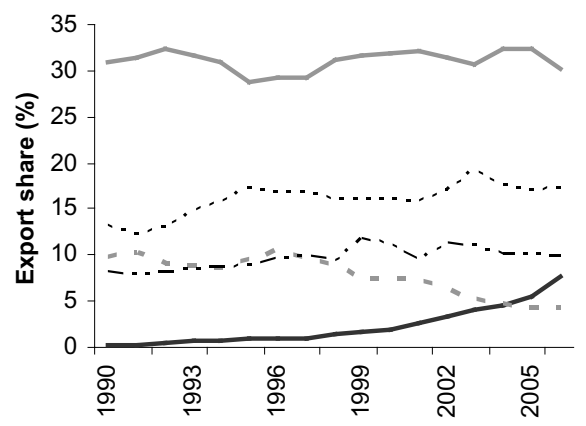

Figure 4.4e Total (reported) imports

Figure $4.4 \mathrm{f}$ Total (reported) exports
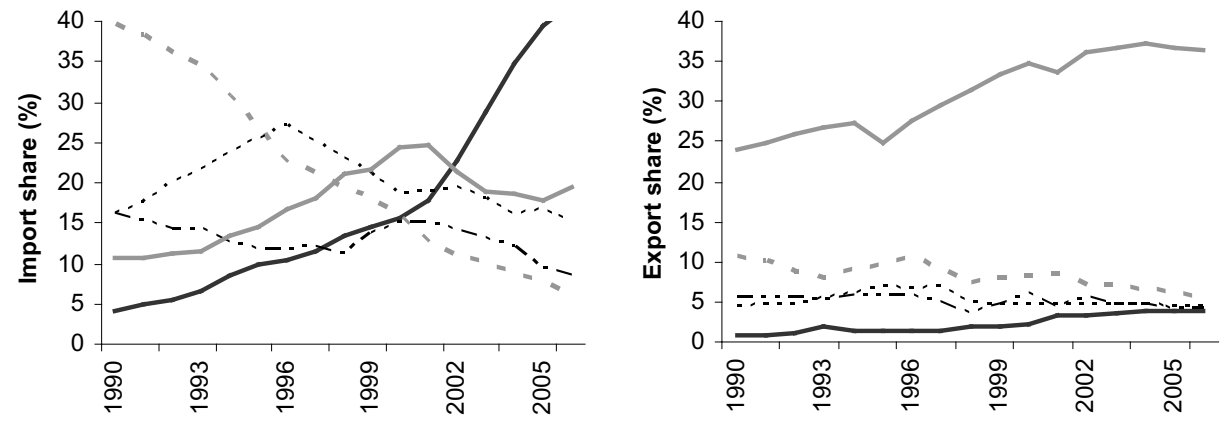
importing of the assembled components to the United States to be incorporated in the final products. Over time, more and more sophisticated stages of the production process were relocated in Southeast Asia, resulting in multiple border crossings of parts and components before they were incorporated in final production not only in the United States, but in other countries covered

\section{Table 4.5 Share of parts and components in US machinery trade} (per cent)

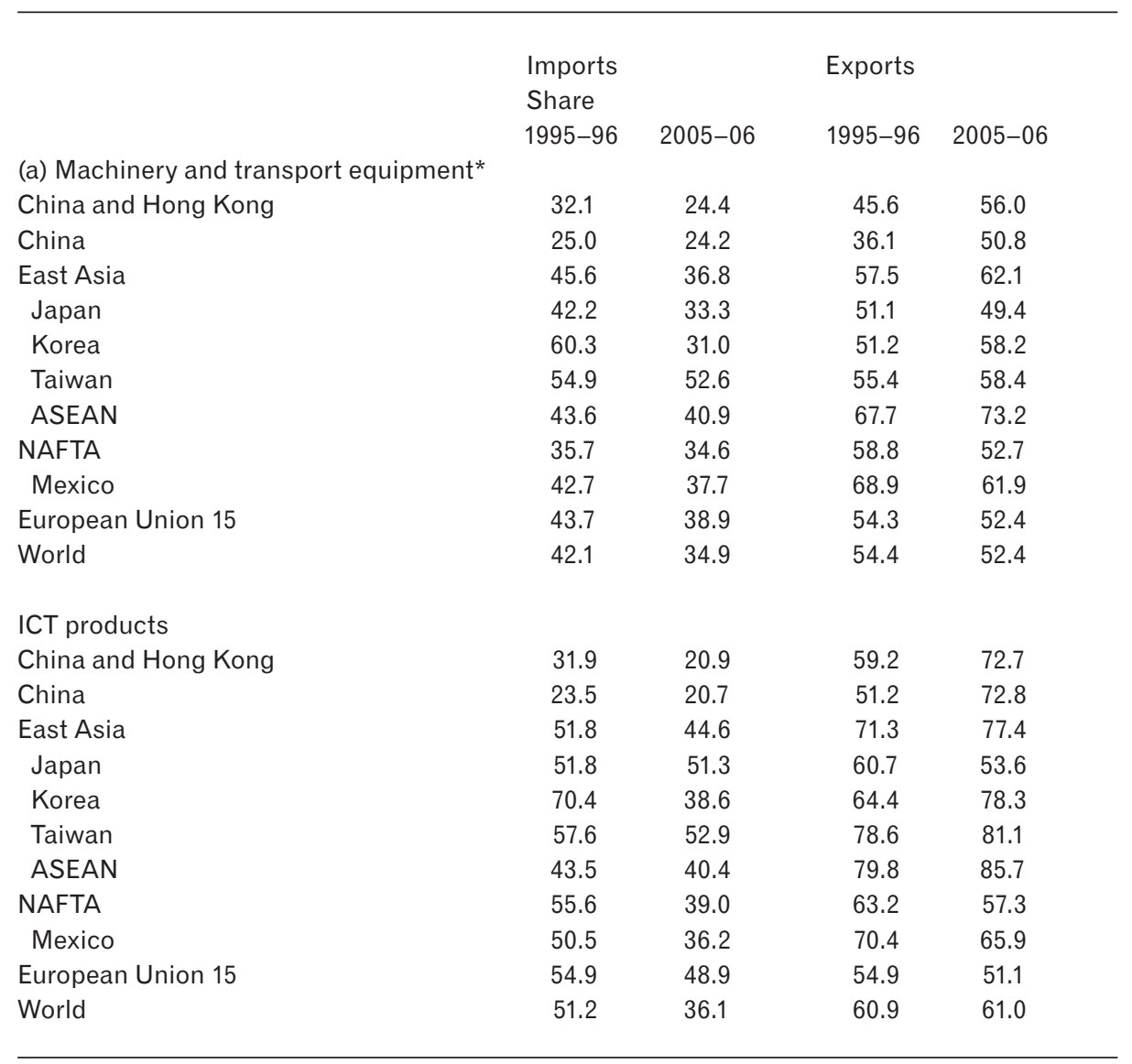

* including ICT products

Source: Compiled from United Nations (UN), various years. Commodity Trade Statistics Database (COMTRADE), Statistics Division, United Nations. Available from http://comtrade. un.org/bd/ 
by the US multinationals' networks (through their own affiliated firms and arm's-length trade relations) (Lipsey 1998; Athukorala 2007). US multinational affiliates in Southeast Asia have, in fact, expanded assembly activities in the region since the emergence of China as the global assembly centre for ICT products and other machinery, and these firms supply parts and components to their own affiliates and other firms involved in assembly operations in China (Athukorala 2007).

Second, the share of parts and components in US imports from China is remarkably low compared with the figures for the other East Asian countries, as well as with the global average. In years for which data are reported, parts and components account for about 20 per cent of total ICT imports to the United States-that is, final goods accounted for nearly four-fifths of total imports. Consequently, the increasing trend of China's penetration in the US ICT markets is much sharper (Figure 4.4) in terms of data for final goods than for figures based on the standard (gross) trade data. Third-and related to the two previous points-two-way trade in parts and components seems to account for a much larger share of trade between the United States and other East Asian countries (in particular, ASEAN countries) compared with trade with China. It seems that China's comparative advantage in global production sharing is still concentrated disproportionately in final assembly.

\section{Determinants of trade flows}

It is clear from the discussion so far that Chain's emergence as an important player in global production networks is an important structural factor behind the widening trade deficit between the United States and China. We now turn to a more formal examination of the determinants of US trade, distinguishing between imports and exports, and focusing on the behaviour of the trade flows of final goods and parts and components within machinery exports. The purpose is to examine whether trade with China has a specific effect on the overall international trade patterns of the United States beyond what can be expected in terms of the standard determinants of bilateral trade flows. The analytical tool used for this purpose is the gravity equation, which has become a standard tool for analysing bilateral trade flows. For the purpose of our analysis, we augmented the basic gravity model in a number of ways to yield the following specification

$$
\begin{aligned}
& \text { LnTRD } D_{i, j}=\alpha+\beta_{1} \ln G D P_{i}+\beta_{2} \ln G D P_{j}+\beta_{3} \ln P G D P_{i}+\beta_{4} \ln P G D P_{j} \\
& +\beta_{5} \ln D S T_{i, j}+\beta_{6} A D J_{i, j}+\beta_{7} \ln R U L C_{i, j}+\beta_{8} \ln R E R_{i, j}+\beta_{9} D C H \\
& +\beta_{10} D J P+\beta_{11} D T W+\beta_{12} D A S+\gamma T+\varepsilon_{i j}
\end{aligned}
$$


in which $i$ and $j$ refer to the reporting country (the United States) and the partner country, and $L n$ denotes natural logarithms. The variables are listed and defined below, with the postulated sign of the regression coefficient for the explanatory variables in brackets.

TRD trade (imports $[M P]$ or exports $[E X]$ ) between $i$ and $j$

$G D P \quad$ real GDP $(+)$

$P G D P \quad$ real GDP per capita (+)

$D S T \quad$ the distance between the economic centres of $i$ and $j(-)$

$A D J \quad$ a binary variable assuming the value of 1 if $i$ and $j$ share a common land border and 0 otherwise $(+)$

$R U L C \quad$ relative unit labour costs of manufacturing between $j$ and $i$ $(E X+; M P-)$

RER an index of bilateral real exchange rates, which measure the international competitiveness between $j$ and $i(E X+; M P-)$

$D C H \quad$ intercept dummy variable for China (+ or -)

DJP intercept dummy variable for Japan (+ or - )

DTW intercept dummy variable for Taiwan and Korea (+ or -)

$D A S \quad$ intercept dummy variable for the five major member countries of ASEAN (Indonesia, Malaysia, Philippines, Singapore and Thailand)

$T \quad$ a set of time dummy variables to capture year-specific 'fixed' effects

a a constant term

$\varepsilon \quad$ a stochastic error term, representing the omitted other influences on bilateral trade.

The first four explanatory variables (GDP, GDPP, $D S T$ and $A D J)$ are the standard gravity-model arguments that do not require further discussion. Among the remaining variables, the relative unit labour cost (RULC, relative manufacturing wages adjusted for labour productivity) is presumably a major factor impacting on the global spread of fragmentation-based specialisation (Jones and Kierzkowski 2001a, 2001b). In a context in which capital and components have become increasingly mobile, the relative cost of production naturally becomes an important consideration in cross-border production. The inclusion of the real exchange rate, $R E R$, which captures the international competitiveness of traded-goods production, is based on a similar reasoning. Another important determinant of trade flows suggested by the theory of production fragmentation is the cost of 'service links' connecting 'production 
blocks' in different countries. There is no unique measure of the cost of service links; however, in our model, distance ( $D S T)$, adjacency $(A D J)$ and per capita income $(P G D P)$ capture certain aspects such as costs. Technological advances during the post-World War II era have certainly contributed to a remarkable reduction in international communication costs. There is, however, evidence that geographical 'distance' is still a key factor in determining international transport costs - in particular, shipping costs-and delivery time (Evans and Harrigan 2003). Timely delivery can in fact be a more important influence on vertical trade than final trade because of multiple border crossings involved in the value-adding chain. The common border dummy $(A D J)$ captures possible additional advantages of proximity that are not captured by the standard distance measure (the greater cycle distance between capital cities). The inclusion of $P G D P$ as an explanatory variable allows for the fact that more industrialised countries have better ports and communication systems and other trade-related infrastructure than developing countries as well as better institutional arrangements for contract enforcement that facilitate trade by reducing the cost of maintaining 'service links'.

The China dummy $(D C H)$ is expected to capture the 'China effect' over and above the other variables. Dummy variables are also included for Japan $(D J P)$, Taiwan and Korea (DTW), ASEAN $(A S N)$ and Mexico $(D M X)$, guided by the empirical regularities in trade patterns observed in the previous section. We observed that China's rapid export expansion in standard labour-intensive manufactures and ICT products has been in direct competition with these countries. It is therefore important to control for any unobserved fixed effects relating to these countries for precise estimation of the 'China effect'. Finally, the time-specific fixed effects $(T)$ are included to control for general technological change and other time-varying factors.

The model was estimated using annual data for machinery trade in the period 1992-2005 for all countries, each of which accounted for 0.1 per cent or more of total manufacturing trade in 2000-01. There were 41 US trading partner countries, which satisfied this criterion. Of these, Hong Kong was combined with China because of its peculiar trade links with the latter. ${ }^{8}$ Our data set therefore relates to 40 countries. Data for bilateral exports are compiled from the importers' records (CIF) of the UN COMTRADE database (UN various years). The data were disaggregated into components and final products following the procedures detailed in Athukorala (2006). The data sources for other variables and methods of variable construction are explained in the appendix.

We use the random-effect estimator as our preferred estimation technique. The alternative fixed-effect estimator is not appropriate because our model contains a number of time-invariant variables. Note that our panel data set 
relates to bilateral trade (imports and exports) for the United States (not bilateral trade flows of all countries under study). This means that the reporting country's (the United States) GDP and PGDP have only 'within variation' in the data panel. It is not possible therefore to retain one or both of these variables and time dummies in the same regression because of multiple co-linearity. After undertaking experimental estimations to see the senility of the results to alternative specifications (with income variables only and time dummies only while keeping all other variables the same), we opted for the version with time dummies. It turned out to be superior to the alternative in terms of the overall fit, and in the economic plausibility and statistical significance of the coefficient estimates of the other variables. This specification choice means that the estimated coefficients of time dummies capture the reporting country's (the United States) income effect and other time-specific factors impacting on trade flows. Relating to the latter, the most noteworthy developments are China's accession to the WTO in 2001 and the subsequent tariff reductions, and the abolition of Multifibre Arrangement (MFA) with effect from 2005. The common border dummy $(B R D)$ could not be retained in the final estimation because of its high correlation with the distance variable. This is not surprising given the United States' high intensity of trade with its two neighbours, Mexico and Canada. We also tested additional dummy variables for Canada and North American Free Trade Agreement (NAFTA) membership (in place of the Mexico dummy) in experimental runs. Both variables turned out to be statistically insignificant over and above the other variables, and they had no significant effect on the size/statistical significance of the other coefficients in the regressions. The regression results are reported in Table 4.6.

The results for the distance variable (DST) provide strong support for the hypothesis that transportation and other distance-related costs are important determinants of trade flows. For total manufacturing, there is evidence of a symmetrical effect of distance on trade: the distance coefficient of import and export equations is remarkably similar in magnitude (1.18 and 1.12, respectively). Interestingly, at the disaggregated level, the distance coefficient for components and final goods of machinery imports are much larger than the coefficients of other manufacturing and total manufacturing. ${ }^{9}$ This difference is consistent with the hypothesis that vertical specialisation, given the multiple border crossings involved in the production process, is much more sensitive to transport costs. The distance coefficients on exports of parts and components and final goods are smaller in magnitude than the respective coefficients on the import side. This asymmetry in the distance effect is consistent with the increased concentration over time of US machinery exports, in particular ICT exports, 
in 'high value-to-weight' segments of the production process within global production networks - a process that seems to have helped US exporting firms to overcome trade barriers associated with distance. The distance coefficient of machinery parts and components exports is, however, much larger (1.26) than that of final machinery (0.91), presumably because speedy delivery is a relatively more important determinant of success in components exports trade than in trade in final goods. This inference is consistent with the recent tendency (observed in the previous section) of US multinationals to expand components assembly and testing in Southeast Asia for supply to the final assembler in China (and other countries in the region). The coefficient of per capita GDP is highly significant and similar in magnitude (about 0.3 ) in the four export equations. This perhaps reflects the heavy industrial-country bias in the geographic patterns of US exports. On the import side, the coefficient is significant only in the two machinery equations. Moreover, the coefficient of the final goods equation is almost twice that of parts and components. It seems that inter-country differences in the stage of economic development are important to imports to the United States taking place within global production networks, in particular final goods.

The coefficient of the relative unit labour cost variable $(R U L C)$ is statistically significant with the expected (negative) sign only in the equation for final machinery imports. It suggests that, other things being equal, a 1 percentagepoint difference among exporting countries is associated with 0.35 per cent difference in growth of exports of this product category to the US market. This unique result is consistent with the important role played by relatively low unit labour costs in the rapid penetration of ICT products and other assembled goods from China in the US market.

Turning to results for the real exchange rate $(R E R)$, on the import side, its coefficient is barely significant with the unexpected (positive) sign in the equation for final machinery and is not different from zero in the other three equations. On the export side, the coefficient carries the expected (positive) sign in all four equations and it fails to achieve significance only in the machinery parts and components equation. The coefficients are, however, rather smallless than 0.1 in all cases. Overall, there is no evidence here to suggest that the exchange rate plays a significant role in determining the United States' widening trade gap. ${ }^{10}$ These results are generally consistent with the available evidence that global production sharing considerably weakens the link between the degree of exchange and trade performance, particularly when it comes to the components trade (Gron and Swenson 1996; Swenson 2000). 


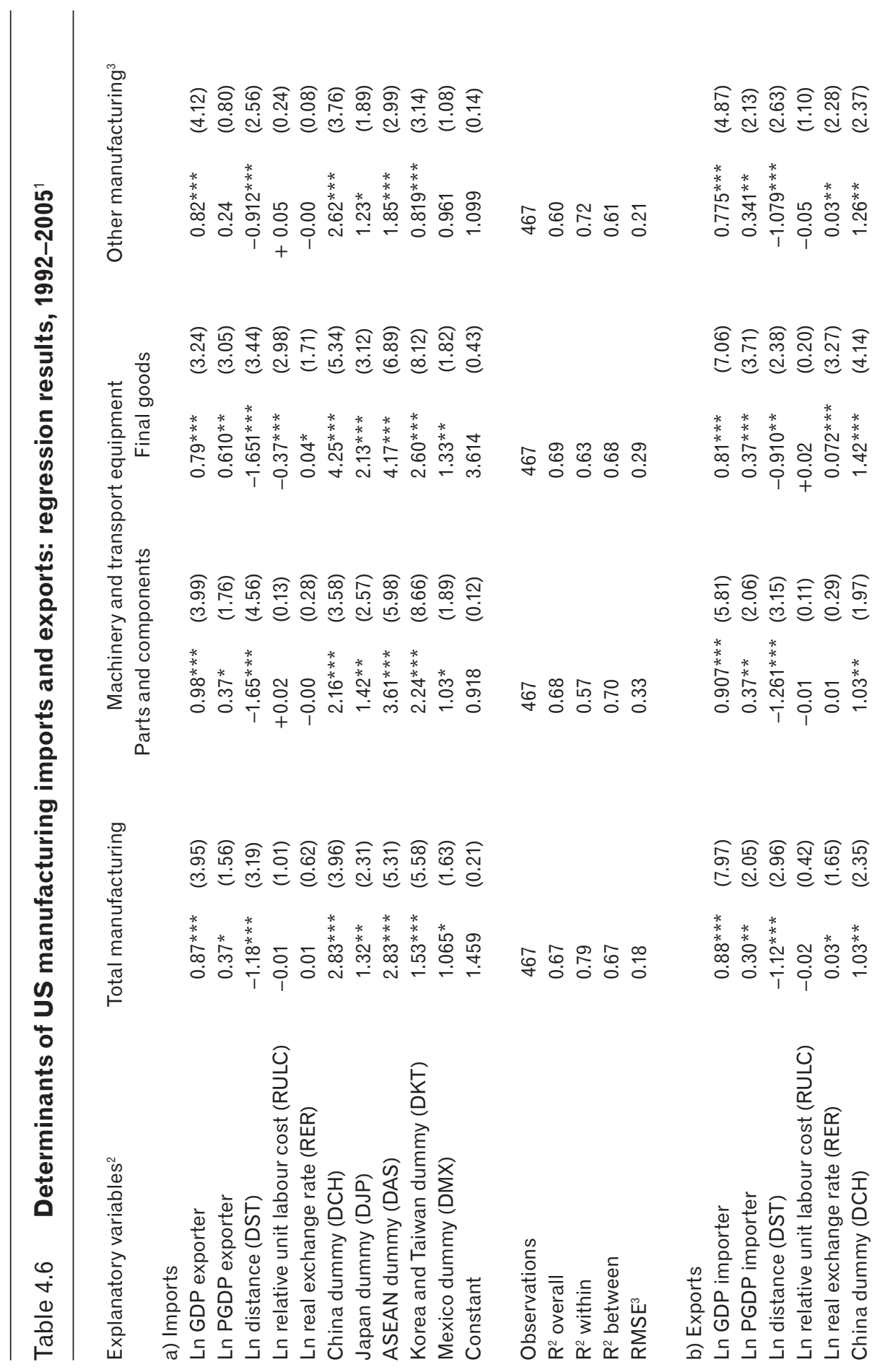




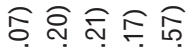

ㄴ

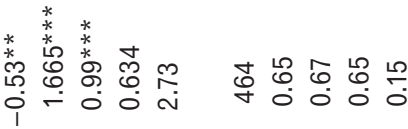

สิ

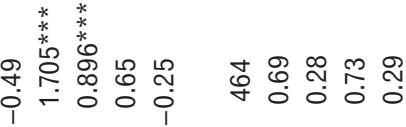

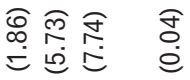

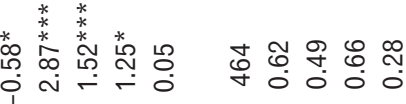

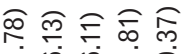

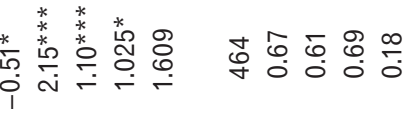

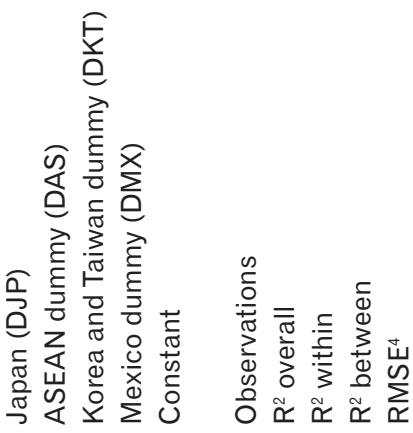

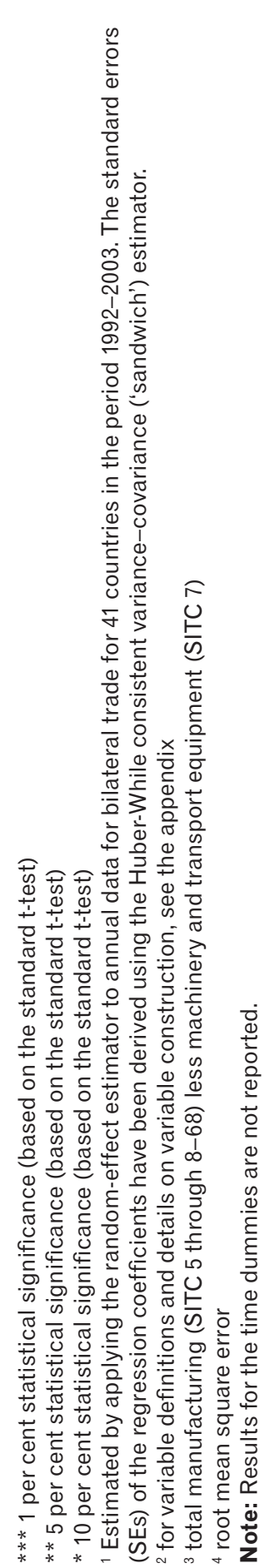


The coefficient of the China dummy $(D C H)$ is positive and statistically significant in all equations. ${ }^{11}$ It is much larger in the import equations, indicating that, after controlling for the standard determinants of trade flows, exports from China have penetrated the United States at a rate much higher rate (on average, 16 times) than those from other countries. The coefficient of $D C H$ in the final machinery export equation is strikingly large (4.25) and is almost twice that in the equation for parts and components (and total manufacturing). This result is consistent with the dominant 'assembly bias' in the emerging patterns of China's export specialisation, which we observed in the previous section. The differences in magnitude among the coefficients of $D C H, D A S, D K T$ and $D M X$ in each of the four import equations are also consistent with the observed differences in relative export performance. The much larger coefficient of the ASEAN dummy in the component equation (3.61) is particularly noteworthy. As discussed, the explanation seems to lie in economic history: the early choice of the region by multinational companies as a location for components assembly and testing in their global production networks.

On the export side, there is no evidence to suggest that US firms perform relatively poorly in exporting to China compared with exports to other countries. The coefficient of $D C H$ is greater than unity and is statistically significant in all cases, suggesting that, once other determinants are controlled for, on average, exports to China have grown almost three times faster than exports to other destinations. The results for the dummy variables also do not reveal any notable difference in the rates of expansion of exports to the United States from China and Mexico when other relevant variables are controlled for-in particular, the specific adjacency/distance advantage of Mexico. A comparison of the results for China and ASEAN corroborate our earlier observation of the growing complementarity among these countries in their trade links with the United States within global production networks.

\section{Concluding remarks}

The evidence harnessed in this chapter supports the view that, in a context in which international fragmentation of production is becoming the symbol of economic globalisation, the standard trade-flow analysis leads to misleading inferences about the sophistication of China's emerging export patterns. Although China has displayed a rapid increase in exports of high-tech products in recent years, the real value added in China is generally not in high-tech activities. When components are netted out, it becomes clear that China is specialising in labour-intensive niches within otherwise skill-intensive sectors. China's general patterns of trade are much in line with its underlying comparative advantage in labour-intensive production. 
In the contemporary international economy, in which global production sharing is expanding rapidly, the real story behind the US-China trade gap is much more complicated than what is revealed by the standard trade-flow analysis undertaken with data coming from a data-reporting system developed at a time when countries were trading predominantly (if not solely) in final goods. The widely held view that China's rapid market penetration of the US economy is driven by unfair trade practices needs to be re-examined in light of the fact that the two economies are deeply interconnected and interdependent within global production networks. The growing trade deficit between the two countries has been underpinned by China's emergence as the main point of final assembly in Asian production networks based on its ample supply of labour and moves by US firms to supply high-end parts and components from their Asian bases. In sum, the deficit is to a large extent a structural deficit driven by the process of global production sharing. It is akin to the substantial structural surplus in the oil-exporting countries (based on their specific resource endowment), which the rest of the world has become accustomed to living with.

Given the current state of China's factor-market conditions (as surveyed in a number of recent studies, including Cooper 2006; Meng and Bai 2007; Naughton 2007), one can speculate that China's trade patterns are unlikely to change dramatically in the short to medium term. China still has about half of its labour force employed in agriculture, where its productivity is, on average, barely one-eighth of that in industry and about one-quarter that in the service sector. Agriculture still accounts for more than 45 per cent of total employment in the country even though agriculture's share in GDP is only 13 per cent. GDP per worker in the economy as a whole is three times the value added per worker in agriculture. The country still remains very rural, with an urbanisation rate of about 40 per cent of the total population-much lower than the 'normal' level of 60 per cent consistent with China's income level. These features, coupled with the high skilled-unskilled wage differential (which, according to some estimates, has risen from 1.3 to 2.1 in the past decade), suggest that China still has much potential for moving unskilled workers out of agriculture and into manufacturing and other productive urban-sector activities. For this to happen, the global trading environment needs to remain accommodative and Chinese policies need to be receptive to gains from specialisation on the basis of comparative advantage.

Given the current state of data, in this chapter, we have focused solely on US-China trade in goods. The inferences therefore need to be qualified for the fact that the difference between merchandise trade and services trade has become increasingly blurred because of the continuing process of production fragmentation. US firms that have shifted components production/assembly 
and final assembly activities and that manage 'service links' involved in the global production networks from their home bases undertake knowledge-based or information technology-enabled services (Brown and Linden 2005). In other words, as part of the continuing process of global production sharing, the related services-particularly knowledge-based or information technology-enabled services that are beyond the traditional notion of internationally traded services, such as transportation, travel and tourism - have become increasingly tradable. There is evidence that exports of these new production-related services (and the related employment opportunities) have significantly expanded in recent years (Mann 2006). The surplus in US services trade (which has persisted since the late 1970s) has expanded rapidly in recent years, reaching US $\$ 75$ billion in 2006 . The largest subcategory - the export growth of which has far outpaced growth in all other services-in the services account is 'other private services' trade, which captures many of the information technology-related services, management and consultancy services and business, professional and technical services, all of which are central to the process of global production sharing..$^{12} \mathrm{An}$ analysis that overlooks these exports could overstate the magnitude of the US-China trade imbalance, presumably by a wide margin.

\section{Notes}

1 In the recent literature on international trade, an array of alternative terms has been used to describe this phenomenon, including 'international production fragmentation', 'vertical specialisation', 'slicing the value chain' and 'outsourcing'.

2 The data reported in this chapter, unless otherwise stated, come from the UN COMTRADE database. Throughout the chapter, inter-temporal comparison calculations are made for the two-year averages relating to the end points of the period under study so as to reduce the impact of year-to-year fluctuations of trade flows.

3 According to available estimates, 70 per cent or more of assembled products are sold domestically (Bergsten et al. 2006:90).

4 Exports by US multinational affiliates in China to the United States accounted for only 6 per cent of total US imports from China in 2004 (Bosworth and Collins 2008:Table 5)

5 For instance, the typical notebook computer made in a Taiwanese-owned factory in China has processing chips made by Intel in Malaysia, an operating system made by Microsoft, a CD display screen sourced from Taiwan or Korea and hard-disk drives sourced from Japan. Domestic value added (the cost of labour, components sourced within China and the profit earned by foreign-owned companies in China) is only one-third of the value of output (Dean and Tam 2005).

6 It is important to note that Chinese estimates of the US trade deficit have always been lower than the United States' own figures because of the different ways the United States treats products traded to and from China that pass through Hong Kong. According to estimates by Fung et al. (2006), the official US data tend to overstate the real deficit by about 17 per cent, while the degree of underestimation involved in the Chinese official estimate is as high as 33 
per cent. This discrepancy does not, however, seem to create a serious problem in examining overall trends in the trade gap.

7 For details on this decomposition procedure, see Athukorala (2006).

8 We also treated Hong Kong as a separate country in experimental runs and found that results were insensitive to this alternative specification.

9 The differences are statistically significant at the 1 per cent level or better.

10 In experimental regression runs, we also interacted RER with $C H D$ and failed to detect any specific Chinese effect on the link between $R E R$ and trade flows.

11 Note that, as the model was estimated in natural logarithms, the percentage equivalent for any dummy coefficient is [(dummy coefficient) -1$\left.]^{*} 100\right)$.

12 From 1995 to 2005, US exports of 'other services' grew 143 per cent, compared with 44 per cent growth in all other services, and accounted for 90 per cent of the overall US services trade surplus in 2005-up from 38 per cent in 1995 (CEA 2007).

\section{References}

Athukorala, P.-C., 2006. 'Product fragmentation and trade patterns in East Asia', Asian Economic Papers, 4(3):1-28.

- - 2007. Multinational Enterprises in Asian Development, Edward Elgar, Cheltenham, UK.

——, 2008 (forthcoming). 'Singapore and ASEAN in the new regional division of labour', Singapore Economic Review, 53(3).

Bergsten, C.F., Gill, B., Lardy, N.R. and Mitchell, D., 2006. China: the balance sheet, Public Affairs, New York.

Bosworth, B. and Collins, S., 2008. 'United States-China trade: where are the exports?', Journal of Chinese Economics and Business Studies, 6(1):1-21.

Brown, C. and Linden, G., 2005. 'Offshoring in the semiconductor industry: a historical perspective', in L. Brainard and S.M. Collins (eds), The Brookings Trade Forum 2005: offshoring white-collar work: the issues and implications, Brookings Institution Press, Washington, DC:270-333.

CEPII, various years. Institutional Profiles Database, CEPII. Available from www. cepii.fr/anglaisgraph/bdd/form_instit/login.asp

Council of Economic Advisors (CEA), 2007. Economic Report of the President 2007, US Government Printing Office, Washington, DC.

Cooper, R.N., 2006. How integrated are Chinese and Indian labor into the world economy, Background paper for A.L. Wintersand and S. Yusuf, 2007, Dancing with Giants: China, India, and the global economy, World Bank, Washington, DC. Available from http:/econ.worldbank.org/dancingwithgiants.

Dean, J. and Tam, P.-W., 2005. 'The lap top trail', The Wall Street Journal, 9 June. Easton, N., 2008. 'Make the world go away', Fortune, 157(2):104-6.

Evans, C. and Harrigan, J., 2003. Distance, time and specialization, NBER Working Paper 9729, National Bureau of Economic Research, Cambridge, Mass. 
Fung, K.C., Lawrence, J.L. and Xiong, Y., 2006. Adjusted estimates of United States-China bilateral trade balances: an update, Stanford Center for International Development Working Paper No.278, Stanford University.

Gosh, A. and Rajan, R.S., 2007. 'A survey of exchange rate pass-through in Asia', Asian-Pacific Economic Literature, 21(2):13-28.

Gron, A. and Swenson, D.L., 1996. 'Incomplete exchange-rate pass-through and imperfect competition: the effect of local production', American Economic Review, 86(2):71-6.

Hufbauer, G.C., Won, Y. and Sheth, K., 2006. US-China Trade Disputes: rising tide, rising stakes, Institute for International Economics, Washington, DC.

Jones, R.W. and Kierzkowski, H., 2001a. 'A framework for fragmentation', in S. Arndt and $\mathrm{H}$. Kierzkowski (eds), Fragmentation: new production patterns in the world economy, Oxford University Press, New York:17-34.

- - 2001b. 'Globalization and the consequences of international fragmentation', in R. Dornbusch, G. Calvo and M. Obstfeld (eds), Money, Factor Mobility and Trade: the festschrift in honor of Robert A. Mundell, MIT Press, Cambridge, Mass.:365-81.

Krugman, P., 2008. Trade and wages reconsidered, Paper presented at the 2008 spring meeting of the Brookings Panel on Economic Activity. Available from http://www. princeton.edu/ pkrugman-bpea-draft.pdf

Lardy, N.R., 2005. 'China: the great new economic challenge', in C.F. Bergsten (ed.), The United States and the World Economy: foreign policy for the next decade, Institute for International Economics, Washington, DC:121-41.

Lipsey, R.E., 1998. 'Trade and production networks of US MNEs and exports by their Asian affiliates', in J. Dunning (ed.), Globalization, Trade and Foreign Direct Investment, Elsevier Science Press, Amsterdam.

Mankiw, N.G. and Swagel, P.L., 2005. 'Antidumping: the third rail of trade policy', Foreign Affairs, 84(4):107-12.

Mann, C.L., 2006. Accelerating the Globalization of America: the role for information technology, Institute for International Economics, Washington, DC.

Meng, X. and Bai, N., 2007. 'How much have the wages of unskilled workers in China increased? Data from seven factories in Guangdong', in R. Garnaut and L. Song (eds), China: linking markets for growth, Asia Pacific Press and ANU E Press, The Australian National University, Canberra:151-75.

Naughton, B., 2007. China's Economy: transition and growth, MIT Press, Cambridge, Mass.

Rodrik, D., 2006. 'What's so special about China's exports?', China and the World Economy, 2(1):153-72.

Shirk, S.L., 2007. China: fragile superpower, Oxford University Press, New York. 
Soloaga, I. and L. A. Winters., 2001. ' Regionalism in the Nineties: What Effect on Trade?", North American Journal of Economics and Finance, 12 (1): 1-15.

Steinbock, D., 2008. 'US presidential election 2008: policy implications for USChina trade and investment', China and the World Economy, 16(3):40-56.

Sung, Y.-W., 2007. 'Made in China: from world sweatshop to a global manufacturing centre?', Asian Economic Papers, 6(3):43-72.

Swenson, D.L., 2000. 'Firm outsourcing decisions: evidence from US foreign trade zones', Economic Inquiry, 38(2):175-89.

United Nations (UN), various years. Commodity Trade Statistics Database (COMTRADE), Statistics Division, United Nations. Available from http://comtrade.un.org/bd.

US Department of Commerce (USDC), various years (a). 'Income and employment by industry', National Economic Accounts, Section 6, Bureau of Economics. Available from http://www.bea.gov/bea/dn/nipaweb/SelectTable. asp?Selected=N\#S6.

_- , various years (b). Survey of US Direct Investment Abroad, Bureau of Economics. Available from http://www.bea.doc.gov/bea/uguide.htm\#_1_23.

Weisman, S., 2007. 'Fourth senate seek plenty for China', New York Times, 14 June. Available from http://www.nytimes.com/2007/06/14/business/world

World Bank, various years. World Development Indicators, World Bank, Washington, DC.

Yusuf, S., Nabeshima, K. and Perkins, D., 2007. 'China and India reshape global industrial geography', in A.L. Winters and S. Yusuf (eds), Dancing with Giants: China, India, and the global economy, World Bank, Washington, DC. Available from http:/econ.worldbank.org/dancingwithgiants. 


\section{Table A4.1 Data set used in regression analysis: definition of variables, source and variable construction, and the country coverage}

\section{Variable Definition \\ EXP Value of US bilateral trade in US\$ measured at constant (2000) price}

$G D P$,

$P G D P$

DIST

$A D J$

$R U L C$

Real GDP and real per capita GDP

(at 1995 price)

Weighted distance measure of the measures the bilateral great-circle distance between major cities of each country French Institute for Research on the International Economy (CEPII), which

A binary dummy variable, which takes the value of 1 for countries that share a common land border and 0 otherwise The ratio of unit labour costs (ULC) in country $j$ and country $i$, where ULC is measured as the ratio of the average manufacturing wage to manufacturing value added per worker-both measured in US\$. In construct, an increase (a decrease) in RULC indicates a deterioration (an improvement) in country $j$ 's cost competitiveness relative to $i$ (the United States, in this case)

Real exchange rate:

Equation A1

$$
R E R_{i j}=N E R * \frac{P_{J}^{W}}{P_{i}^{D}}
$$

in which NER is the nominal bilateral exchange rate index (US\$ price of foreign currency), PW is the price level of country $j$ measured by the producer price index and $P D$ is the domestic price index of country $i$ measured by the GDP deflator. By construct, an increase (decrease) in $\mathrm{RER} i j$ indicates a deterioration (an improvement) in country $j$ 's competitiveness in traded-goods production vis-à-vis $i$ (the United States, in this case)

\section{Data source/variable construction}

Trade data (in current US\$) compiled from importer records of UN (various years) (http://www.bls.gov/ppi/home.htm), deflated by the manufacturing subindex of the US producer price index World Bank (various years)

CEPII (various years)

CEPII (various years)

Annual manufacturing wages data for the United States (USDC various years [a])

All other countries: (USDC various years [b])

Constructed using data obtained from World Bank (various years)

Following Soloaga and Winters (2001), mean-adjusted RER is used in the model. This variable specification assumes that countries are in exchange-rate equilibrium at the mean. 


\section{Table A4.2 Country coverage}

\begin{tabular}{llll}
\hline Argentina & Finland & Malaysia & \\
Australia & France & Mexico & Slovakia \\
Austria & Germany & Netherlands & Slovenia \\
Belgium & Hungary & Norway & South Africa \\
Brazil & India & Philippines & Spain \\
Canada & Indonesia & Poland & Sweden \\
China and Hong Kong & Ireland & Portugal & Switzerland \\
Costa Rica & Israel & Republic of Korea & Taiwan \\
Czech Republic & Italy & Russian Federation & Thailand \\
Denmark & Japan & Singapore & Turkey \\
& & & \\
\hline
\end{tabular}

